\title{
The influence of relational factors on successful succession in family businesses: A comparative study of owner-managers and successors
}

\author{
E. Venter* \\ Department of Business Management, University of Port Elizabeth, \\ PO Box 1600, Port Elizabeth 6000, Republic of South Africa \\ ecaeev@upe.ac.za \\ C. Boshoff \\ Department of Business Management, University of Port Elizabeth, \\ PO Box 1600, Port Elizabeth 6000, Republic of South Africa \\ G. Maas \\ International Chair in Entrepreneurship: \\ University of Limerick, Rhodes University and PE Technikon, \\ PE Technikon, Port Elizabeth 6000, Republic of South Africa
}

Received September 2003

\begin{abstract}
Family businesses are fast becoming the dominant form of business enterprise in both developing and developed economies and play a vital economic and social role in these economies. As family businesses are a primary contributor to the economic and social well-being of all capitalist societies, their general lack of longevity is a cause for concern. One of the main reasons (if not the single most important reason) of the high failure rate among first- and second-generation family businesses is their inability to manage the complex process of ownership and management succession from one generation to the next. Hence, the primary objective of this study is to identify the relational or human factors that impact on successful succession. The results indicate that the willingness of the successor to take over the family business, the owner-manager's trust in the successor's abilities and intentions to manage the business, and the owner-manager's interest outside the business are important to the success of succession for both owner-managers and successors. Furthermore, the more the successor perceives harmony within the family, the more satisfied the successor will be with the succession process.
\end{abstract}

*To whom all correspondence should be addressed.

\section{Introduction}

For South Africa, like so many other developing countries, the battle against poverty, and its root cause, unemployment, is a continuous one. Recent figures (2002) indicated that $37 \%$ of households in South Africa survive on less than R1 000 per month (Woolard, 2002). Poverty and unemployment are closely linked, in that $53 \%$ of the South African population falling in the poorest quintile are unemployed, compared to $4 \%$ of the most affluent $20 \%$ of the population.

It is therefore important to find solutions to the unemployment problem in order to give poor South Africans the means of generating a sustained income. Unfortunately, existing large corporations and the public sector have proven unable to address the endemic problems of unemployment and poverty. As a result, the focus has increasingly shifted to the role the small business sector can play in solving the economic crises facing South Africa.
Approximately $80 \%$ of businesses in South Africa could be classified as family businesses (Ackerman, 2001:325; Dickinson, 2000:3; Meyer, 1994:1), which are mostly small to medium-sized (Maas, 1999:2; Magretta, 1998:114; Neubauer \& Lank, 1998:11; Okoroafo, 1999:147; Weinstein, 1999:2). In fact, family businesses are fast becoming the dominant form of business enterprise in both developing and developed economies and play a vital role, both economically and socially in these economies. More importantly, however, the influence and number of family businesses can be expected to increase substantially in the near future. This rapid growth could be attributed to the rationalising process taking place in many large corporations, together with the growing inability of the formal sector to create new jobs. Family businesses can therefore offer powerful opportunities for further economic growth in South Africa.

\section{Problem statement and objectives}

As family businesses are a primary contributor to the 
economic and social well-being of all capitalist societies, their general lack of longevity is a cause for concern. It has been estimated that, internationally, only $30 \%$ of family businesses survive to the second generation, while fewer than $14 \%$ make it beyond the third generation (Bjuggren \& Sund, 2001:12; Engine of growth, 1994:25; Fleming, 1997:46; Leach, 1994:147; Matthews, Moore \& Fialko, 1999:159). In South Africa, only one in four family businesses survive into the second generation, while only one in ten makes it to the third generation (Engine of growth, 1994:25; Hugo, 1996:8). There is no doubt that the economic and social cost of this high failure rate has impacted negatively on economic growth in South Africa.

According to several authors, one of the main reasons (if not the single most important reason) of the high failure rate among first- and second-generation family businesses is their inability to manage the complex and highly emotive process of ownership and management succession from one generation to the next (Corbetta \& Montemerlo, 1998:8; Leach, 1994:147; Magretta, 1998:121; Pilversack \& Scharf, 1994:128; Weinstein, 1999:2). This is particularly true at the time of first transition between the founder and the next generation.

It is apparent that to be able to manage succession properly we need to identify and understand the factors that influence succession in family businesses. Only then can family members address succession proactively. The easier and more successful the transition, the better the chances of survival and long-term profitability. A well-considered and planned succession will maximise the chances of finding a competent successor and will ensure a smooth leadership transition between generations (Neubauer \& Lank, 1998:133).

Against this background, the primary objective of this study is to identify the human or relational factors that impact on successful succession in small and medium-sized family businesses. The potential influence of various factors (independent variables such as family harmony, relationship between owner-manager and successor, and trust in the successor's abilities and intentions) on the dependent variable, namely the Perceived success of the succession process are theoretically modelled and empirically tested.

This study will not only test the existence and magnitude of these relationships, but also compare and contrast which of these factors are important for two major stakeholder groups in the succession process, namely owner-managers and successors. It is important for the continued prosperity of the family business and harmony within the family that family business leaders and all stakeholders have a sound understanding of the critical success factors for succession.

\section{Theoretical background}

\section{Factors influencing succession}

A number of factors that could influence succession in family businesses have been suggested in the literature. Unfortunately the literature is highly fragmented and even incoherent. This lack of agreement and coherence restricts a deeper understanding of the management of succession. In addition, much of the reported literature is based on case studies and consultants' accounts rather than rigorous empirical research, which obviously have inherent limitations. Considerably less attention has been devoted to quantitative studies that employ larger samples and provide empirical tests of relationships between key variables. This limitation can be traced back to inherent measurement difficulties in the family business field, and to the relatively young status of the field itself as a distinct focus of academic attention (Morris, Williams, Allen \& Avila, 1997:386). An exception is the study of Sharma (1997), which identified and empirically tested the relative importance of factors that determine the successful managerial transition from one family member to another in Canada. Sharma's study was also the first attempt towards understanding the succession experience from multiple perspectives, namely the perspectives of successors, predecessors and other family members in the family business.

Although this study focuses on the owner-manager, successor and family characteristics that may influence family business succession, some organisational and external factors that influence the succession process can also be identified (e.g. Handler, 1989; Handler \& Kram, 1988; Harveston, Davis \& Lyden, 1997; Lansberg, 1988; Sharma, 1997; Venter, 2003).

The traditional approach to understanding succession in family businesses has been to focus on the founder or owner-manager and his emotional struggle in passing ownership and control to the successor (Brown \& Coverley, 1999; Goldberg, 1996; Swogger, 1991) or the successor (e.g. File \& Prince, 1996; Goldberg, 1991; Shepherd \& Zacharakis, 2000; Stavrou, 1999). We along with others, however, argue that succession should be viewed from the perspectives of both role players (e.g. Lansberg \& Astrachan, 1994; McConaughy \& Philips, 1999; Sharma, 1997; Sharma, Chua \& Chrisman, 2000; Venter, 2003).

This study thus focuses on the relationship between the owner-manager and the successor and particularly the factors that could influence their relationship.

The quality of the successor's relationship with the founder is a critical determinant of the succession process and is influenced by mutual respect and understanding and sensitivity to each other's needs. Not only does the successor's relationship with the owner-manager influence the perceived success of the succession process, but also his relationship with his siblings. As important as it is for the owner-manager to be willing to hand over the business to a successor (e.g. Birley, 1986:128; Matthews et al., 1999:163; Sharma et al., 2000:236), so too must the successor display an interest and willingness to want to manage the family business (e.g. Berenbeim, 1990:69; Dickinson, 2000:38). This willingness to take over the family business may be influenced by how well the successor's career interests and other personal needs are aligned with opportunities in the business; whether the opportunity exists to exercise influence in the business; and the possible rewards from the 
business. On the other hand, owner-managers who develop strong interests in activities other than the management of the family business generally have an easier time planning their succession. As retirement is generally a difficult issue for incumbents, it may be helpful for them to develop outside interests to ease themselves into retirement (e.g. Ciampa \& Watkins, 1999; Costa, 1997; Donckels \& Lambrecht, 1999; Lansberg, 1999; Matthews et al., 1999; Muson, 1997; Sharma, 1997).

The reluctance on the part of the owner-manager to let go of the business may be underpinned by feelings of doubt about the successor's ability, willingness and desire to take control (Goldberg \& Wooldridge 1993: 70). Trust in the successor's ability to manage the family business; the extent of identity with the business; and interest in activities other than the management of the family business, are of particular importance where the succession process is concerned, as they may affect the ease with which the incumbent is willing to hand over the business to a successor (Correll, 1989:24; Dickinson, 2000:37; Donckels \& Lambrecht, 1999:177; Goldberg \& Wooldridge, 1993:63; Matthews et al., 1999:163; Venter, 2003:186).

Although the relationship between the business leader and his successor is of the utmost importance, Santiago (2000) suggests that a more critical element for a smoother leadership transition is the relationship among family members. A major proportion of literature on family business has been devoted to understanding the influence of the family on the business (e.g. Danes, Rueter, Kwon \& Doherty, 2002; Donnelley, 1988; Dunn, 1999; Friedman, 1991; Handler, 1989; James, 1999; Lansberg \& Astrachan, 1994; Santiago, 2000; Seymour, 1993; Swogger, 1991). The literature on family systems suggests that family structures and patterns of interaction can have an impact on the dynamics of family business management (Handler \& Kram, 1988:365). According to Donnelley (1988:428), family relationships influence succession by either facilitating or hindering succession planning and training (Lansberg \& Astrachan, 1994:41). If the choice of a successor from among the siblings is interpreted as parental favouritism, dysfunctional rivalries could be unleashed among brothers and sisters (Friedman, 1991: 11), which could complicate and delay the succession transition. Conversely, families that are mutually supportive and work well together are more likely to effectively transfer the business to the next generation.

It could be argued that harmony within the family business may make the succession planning process a more tolerable task and that harmonious relationships may reinforce the importance of succession planning in the owner's mind. It is also possible that the planning effort itself could serve to clarify ambiguous relationships and problems, thus serving to increase the level of harmony in the family (Malone, 1989:349). Chrisman et al (1998:20) argue that the trust and respect of family members not actively involved in the business may be just as important to the successor, because they may be the most influential persons. The succession process can be sabotaged when power imbalances and conflict within the family permeate the family business (Handler \& Kram, 1988:376). A proactive problem-solving approach to conflict management in the family could provide the basis for a positive problem-solving orientation in the business, which is vital for succession between generations (Dyer, 1994:117; Handler, 1994:149; Harvey \& Evans, 1995:4; Ryan, 1995:13; Sorenson, 1999:133).

To summarise: the literature suggests that five human relational variables can influence the success of management succession namely: the willingness of the successor to take over the business (WILLING), family harmony (HARMONY), the nature of relationship between owner-manager and successor (RELATION), the ownermanager's outside interests (INTEREST), and trust in the successor's abilities and intentions (TRUST).

\section{The dependent variable}

There is still no consensus on what constitutes a successful or effective succession (Handler, 1989:259; Santiago, 2000:20; Stempler, 1988:6). It has been suggested (Handler, 1989:212; Morris et al., 1997:390) that a distinction should be made between the quality of the experience (how family members personally experience the process) and the effectiveness of the succession (how others judge the outcome of the transition). Handler (1989:216), Sharma (1997:11) and Stempler (1988) suggest that the satisfaction of predecessor, successor, and other family members with the succession process can be used as an indication of the perceived success of the succession process.

Others, such as Goldberg (1996:186), Harvey and Evans (1995:12) and Hume (1999:22), recommend that not only the satisfaction of various stakeholders with the succession process defines a successful succession, but also the successor's ability to keep the family business healthy by means of sustained growth and continued profitability. Santiago (2000:20) argues that if the leadership transition was so smooth that the change did not disrupt the family or the business, then the succession could be labelled highly successful. If the succession process faced some challenges, but the family and its business functioned well after the change of leadership, then the succession could be considered successful. If either the business or the family did not function well as a result of the change, then the succession could be considered moderately successful. Finally, if both the family and its business failed to function well following the transition (i.e. the business was financially unstable and the family experienced open conflict), the succession could be considered unsuccessful.

It therefore appears that in order to ensure the success of the succession process, all the different stakeholders involved in the process (the predecessor, successor, family, network, suppliers, etc.) must be satisfied with its outcomes, and the successor should have the ability to ensure the sustainability and financial security of the family business after the succession process has been completed. 


\section{Methodology}

\section{The measuring instrument}

A theoretical model of factors that could influence successful succession was generated, based on a comprehensive review of the family business literature. All the items on the questionnaire were linked to a 7-point Likert-type scale. As far as possible instruments were used that have demonstrated acceptable psychometric properties in previous empirical studies. Where that was not possible self-generated instruments were used to measure some of the variables in the theoretical model.

\section{The sample}

Questionnaires were mailed to a convenience sample of 2458 respondents in 1038 small and medium-sized family businesses (employing fewer than 200 workers) in South Africa. A total of 332 usable questionnaires were returned. This was a more than adequate sample size for the use of multivariate statistical techniques such multiple regression analyses (Hair, Anderson, Tatham \& Black, 1995:103-105) to analyse the data.

The 332 questionnaires were evenly split between three of the four individual respondent groups, with 106 questionnaires received from potential successors; 103 received from successors; and 91 from retiring ownermanagers. As can be expected, only 32 questionnaires were received from retired owner-managers, as they were more difficult to reach by virtue of the fact that they had already retired and left the business, or were deceased.

Altogether 135 of the respondents indicated that succession had already taken place in their businesses, while 197 of the respondents indicated that succession had not taken place yet, but was planned to take place in the near future. These figures are consistent with the number of respondents in the retired owner-manager and successor groups who had obviously already experienced succession, and the number of respondents in the retiring owner-manager and potential successor groups who were still awaiting the succession process. Overall, 53\% of the planned successions would take place within the next five years, while $84 \%$ would take place in the next ten years.

Altogether $34 \%$ of respondents had businesses that employed less than ten employees, and a further $30 \%$ employed between ten and nineteen employees. Only 6\% employed more than 100 (but not more than 200) employees. This sample composition is consistent with the findings from previous research and indications in the literature that the majority of SMEs in South Africa employ fewer than twenty people (Laubscher, 1993:96; Maas, 1999:3).

Possibly as a function of the sampling technique used, almost half the respondents (49\%) were in the agricultural sector, with $23 \%$ in the retailing and $19 \%$ in the service industry.

Considering that the majority of respondents were either successors $(31 \%)$ or potential successors $(32 \%)$, most of the respondents were from the non-founding generation, with $47 \%$ from the second generation and $18 \%$ from the third generation. However, $23 \%$ of respondents were still from the founding (first) generation.

By far the greater majority of respondents $(81 \%)$ indicated that their families owned more than $50 \%$ of the controlling share in the business and that between two (32\%) and four $(36 \%)$ family members were employed on a full-time basis to look after the family's interests. Sole proprietorship at $29 \%$ and close corporations at $27 \%$ were the most prevalent business forms. Most current owner-managers were European $(97 \%)$ and male $(90 \%)$, while at least $11 \%$ of the potential successors were identified as female.

\section{The statistical analysis of the data}

The analysis of the data consisted of three phases. Initially the data were subjected to an exploratory factor analysis to assess the discriminant validity of the measuring instrument. This was followed by an assessment of the reliability of the instrument by means of an internal consistency measure (Cronbach Alpha). The items that remained were included in the regression model to assess the impact of succession factors on the dependent variable, namely successful succession.

\section{Data analysis procedures}

\section{Validity of the measuring instrument}

The first phase of data analysis involved an assessment of the discriminant validity of the measuring instrument. The validity of a measuring instrument refers to the extent to which a measure or set of measures correctly represents the concept of study. It is therefore concerned with how well the concept is defined by the measure(s) (Hair, Anderson, Tatham \& Black, 1998:90).

The multivariate technique of exploratory factor analysis was used in this study to assess the discriminant validity of the measuring instrument. The main purpose of exploratory factor analysis is to identify the substructures in the data matrix. The computer programme BMDP4M was used to conduct the exploratory factor analysis (Frane, Jennrich \& Sampson, 1990). Maximum Likelihood was specified as the method of factor extraction, and a direct quartimin oblique rotation of the original matrix was used (Jennrich \& Sampson, 1996).

\section{Reliability of the measuring instrument}

In this study, the Cronbach alpha reliability coefficient was used to assess the internal consistency of the entire scale. The generally agreed lower limit for the Cronbach alpha coefficient is 0,70 , although it may be decreased to 0.60 in the case of exploratory research (Hair et al., 1998: 118).

\section{Multiple linear regression}

In order to compare whether the owner-managers and successors have different perceptions of which factors 
influence the success of succession (Satisfaction with succession process and the Continued profitability of the business), the data set was divided into two sub-samples, the first consisting of responses received from the 123 ownermanagers (both retired and retiring owner-managers) and the second consisting of responses received from the 209 successors (potential or current successors). Multiple linear regression analysis was performed to assess whether the following ordinal factors exerted a significant influence on Satisfaction with the succession process (SATISFIED) and Continued profitability of the business (PROFIT) for these two sub-samples separately:

For this purpose, the following null hypotheses were defined for owner-managers and successor respectively:

$H^{0 a}: \quad$ For owner-managers, there is no relationship between the identified factors and the satisfaction with the succession process.

$H^{0 b}$ : For owner-managers there is no relationship between the identified factors and the continued profitability of the business.

$H^{0 c}$ : For successors, there is no relationship between the identified factors and the satisfaction with the succession process.

$H^{\text {od }}$ : For successors there is no relationship between the identified factors and the continued profitability of the business.

\section{Results}

\section{Discriminant validity results}

Table 1 shows that after 6 iterations, 31 items from the questionnaire loaded on 7 distinct factors explaining a total of $58,36 \%$ of the variance in the data. Table 1 also shows that during the exploratory factor analysis, the dependent variable (in this study being the Perceived success of the succession process) had split into two variables, namely Satisfaction with the succession process (SATISFIED) and Continued profitability of the business (PROFIT) - hence the need to formulate two additional hypotheses $\left(H^{0 b}\right.$ and $H^{\text {od }}$ ).

Factors 5 and 7 are the dependent variables in the regression analysis and represent the Continued profitability of the business (PROFIT) and the Satisfaction with succession process (SATISFIED) respectively.

\section{Reliability results}

Cronbach alpha coefficient scores of more than 0.70 were recorded for all factors and the questionnaire items used to measure the various constructs and thus the measuring instrument can therefore be considered reliable (see Table 1 above).

The stated hypotheses were tested by means of regression analyses. As two dependent variables emerged from the exploratory factor analysis (Satisfaction and Future Profitability), four separate multiple regression analyses had to be conducted - two for each sub-sample.

\section{Multiple regression results for the owner-manager sub-sample: Satisfaction}

Table 2 shows that two of the independent variables namely Willingness to take over the business (WILLING) and Trust in the successor's ability (TRUST) exert a significant positive influence on the dependent variable Satisfaction. The relationship between Trust and Satisfaction is significant at the $1 \%$ level and between Willingness and Satisfaction at the $5 \%$ level. These relationship imply that if the owner-manager perceives the successor to be willing to take over the business and the more the owner-manager has trust in the successor's abilities and intentions to manage the family business in the future, the more satisfied the ownermanagers will be with the succession process. Table 2 shows that the independent variables in the multiple regression analysis explain $21,1 \%$ of the variance of in dependent variable Satisfaction.

The null hypothesis $\left(\mathrm{H}^{0 \mathrm{aa}}\right)$ of no relationship with the dependent variable Satisfaction with the succession process is thus rejected in respect of Willingness to take over the business and Trust.

\section{Multiple regression results for the owner-manager sub-sample: Future profitability}

According to Table 3 two of the independent variables also influence the perceived future profitability of the family business. Both Willingness to take over the business (WILLING) and the extent of the owner-manager's Outside interest (INTEREST) exert a significant positive influence on the dependent variable PROFIT at the $1 \%$ level and the $0,1 \%$ level of significance respectively. This means that the more the owner-manager perceives the successor to be willing to take over the business and the more the ownermanager has interests outside of the family business, the more likely the business is to remain profitable. In total, the independent variables explain $38,0 \%$ of the variance in the dependent variable (PROFIT).

The null hypothesis $\left(\mathrm{H}^{0 b}\right)$ of no relationship with the dependent variable Continued profitability of the business is thus rejected in respect of Willingness to take over the business and the Outside interests of the owner-manager. 
Table 1: Exploratory factor analysis result ${ }^{(\mathrm{I})}$

\begin{tabular}{|c|c|c|c|c|c|c|c|}
\hline ITEM & \begin{tabular}{|c|} 
FACTOR 1 \\
$\begin{array}{c}\text { Willingness of } \\
\text { successor to take } \\
\text { over }\end{array}$ \\
\end{tabular} & \begin{tabular}{|c|} 
FACTOR 2 \\
Family harmony
\end{tabular} & \begin{tabular}{|c|} 
FACTOR 3 \\
Relationship \\
between owner- \\
manager \& \\
successor \\
\end{tabular} & \begin{tabular}{|c|} 
FACTOR 4 \\
Outside interests \\
\end{tabular} & $\begin{array}{c}\text { FACTOR } 5 \\
\begin{array}{c}\text { Continued } \\
\text { profitability of } \\
\text { business }\end{array}\end{array}$ & $\begin{array}{c}\text { FACTOR } 6 \\
\text { Trust in } \\
\text { successor's } \\
\text { abilities \& } \\
\text { intentions } \\
\end{array}$ & \begin{tabular}{|c} 
FACTOR 7 \\
Satisfaction with \\
succession \\
process
\end{tabular} \\
\hline $\mathrm{WTO}^{(2)}$ & 0,855 & 0,059 & 0,084 & 0,048 & $-0,047$ & 0,001 & $-0,048$ \\
\hline PNA1 & 0,838 & 0,012 & $-0,021$ & $-0,040$ & 0,074 & $-0,043$ & $-0,005$ \\
\hline WTO5 & 0,781 & $-0,120$ & $-0,103$ & $-0,026$ & 0,092 & 0,057 & 0,171 \\
\hline AGR4 & 0,702 & 0,109 & 0,073 & $-0,040$ & $-0,058$ & 0,007 & $-0,038$ \\
\hline WTO1 & 0,691 & $-0,047$ & 0,012 & $-0,040$ & 0,018 & 0,025 & 0,152 \\
\hline WTO7 & 0,680 & 0,048 & 0,093 & 0,119 & 0,047 & $-0,160$ & $-0,025$ \\
\hline PNA2 & 0,571 & 0,048 & 0,007 & $-0,013$ & 0,015 & 0,177 & $-0,004$ \\
\hline PNA4 & 0,564 & 0,141 & $-0,091$ & $-0,048$ & 0,034 & 0,183 & 0,040 \\
\hline TRU5 & 0,553 & $-0,000$ & 0,147 & 0,169 & 0,160 & 0,012 & $-0,123$ \\
\hline FH4 & 0,072 & 0,898 & $-0,002$ & $-0,117$ & $-0,035$ & 0,000 & $-0,050$ \\
\hline FH6 & 0,050 & 0,819 & 0,053 & 0,060 & 0,088 & $-0,061$ & $-0,060$ \\
\hline FH3 & 0,058 & 0,710 & 0,038 & 0,019 & $-0,086$ & 0,191 & 0,047 \\
\hline FH1 & 0,045 & 0,653 & $-0,110$ & 0,096 & $-0,072$ & 0,071 & 0,146 \\
\hline FH5 & $-0,022$ & 0,567 & 0,191 & 0,029 & 0,093 & $-0,009$ & 0,065 \\
\hline SUC3 & 0,060 & 0,549 & 0,056 & $-0,025$ & 0,184 & $-0,024$ & 0,190 \\
\hline REL7 & 0,053 & $-0,083$ & 0,738 & 0,109 & 0,004 & 0,152 & 0,059 \\
\hline REL4 & $-0,015$ & 0,079 & 0,725 & 0,029 & 0,121 & 0,083 & 0,025 \\
\hline REL5 & 0,104 & 0,005 & 0,551 & $-0,031$ & $-0,042$ & $-0,080$ & 0,107 \\
\hline REL6 & $-0,086$ & 0,252 & 0,475 & $-0,029$ & 0,063 & 0,222 & $-0,059$ \\
\hline OI2 & 0,066 & $-0,128$ & $-0,049$ & 0,773 & $-0,029$ & 0,056 & 0,044 \\
\hline OI1 & $-0,106$ & $-0,009$ & $-0,030$ & 0,699 & 0,089 & 0,028 & $-0,037$ \\
\hline OI5 & 0,071 & 0,020 & 0,031 & 0,574 & $-0,016$ & $-0,041$ & $-0,027$ \\
\hline OI3 & $-0,020$ & 0,101 & 0,044 & 0,521 & $-0,062$ & 0,004 & 0,038 \\
\hline SUC1 & $-0,009$ & $-0,001$ & 0,002 & $-0,022$ & 0,914 & 0,025 & $-0,028$ \\
\hline SUC10 & 0,068 & 0,001 & $-0,002$ & $-0,005$ & 0,603 & 0,000 & 0,053 \\
\hline TRU7 & 0,129 & $-0,022$ & 0,265 & 0,001 & 0,013 & 0,686 & $-0,011$ \\
\hline TRU4 & $-0,067$ & 0,119 & 0,046 & 0,120 & 0,015 & 0,580 & 0,131 \\
\hline TRU2 & 0,251 & 0,058 & $-0,045$ & 0,023 & 0,215 & 0,567 & 0,040 \\
\hline SUC8 & 0,033 & 0,049 & 0,100 & 0,003 & $-0,028$ & 0,050 & 0,744 \\
\hline SUC6 & 0,107 & 0,018 & 0,191 & $-0,008$ & 0,176 & 0,028 & 0,525 \\
\hline SUC5 & $-0,061$ & 0,367 & $-0,048$ & 0,130 & 0,148 & 0,042 & 0,440 \\
\hline Cronabach Alpha & 0,890 & 0,890 & 0,780 & 0,740 & 0,740 & 0,800 & 0,770 \\
\hline Eigen Value & 10,13 & 3,18 & 2,24 & 1,65 & 1,45 & 1,16 & 1,07 \\
\hline
\end{tabular}

(1) Loadings greater than 0,40 were considered significant.

(2) A full description of the different items used in the factor analysis can be found in Appendix A.

The five factors (independent variables in the subsequent regression analyses) that were retained were:

Factor 1: Willingness of the successor to take over the business (WILLING)

Factor 2: Family harmony (HARMONY)

Factor 3: Relationship between owner-manager and successor (RELATION)

Factor 4: Owner-manager's outside interests (INTEREST)

Factor 6: Trust in the successor's abilities and intentions (TRUST) 
Table 2: Multiple regression results for owner-manager sub-sample: Satisfaction

Dependent Variable: SATISFACTION

\begin{tabular}{l|c|c|c|c|c}
\hline Source & DF & Sum of Squares & Mean Square & F Value & Pr>F \\
\hline Model & 5 & 269,915 & 53,983 & 6,27 & 0,0001 \\
\hline Error & 117 & 1007,011 & 8,607 & & \\
\hline Corrected Total & 122 & 1276,927 & & & \\
\hline
\end{tabular}

$$
\mathrm{R}^{2}=21,1 \%
$$

\begin{tabular}{l|c|c|c|c}
\hline Parameter & Estimate & T for H0: Parameter=0 & Pr> $\mathbf{T}]$ & Std Error of Estimate \\
\hline INTERCEPT & 3,663 & 1,31 & 0,194 & 2,805 \\
\hline WILLINGNESS & 0,125 & 1,93 & $0,049^{*}$ & 0,065 \\
\hline FAMILY HARMONY & 0,083 & 1,02 & 0,310 & 0,082 \\
\hline INTEREST & 0,007 & 0,07 & 0,945 & 0,104 \\
\hline TRUST & 0,295 & 2,92 & $0,004 * *$ & 0,101 \\
\hline RELATION & 0,022 & 0,29 & 0,776 & 0,076 \\
\hline
\end{tabular}

$* \mathrm{p}<0,05$

$* * \mathrm{p}<0,01$

$* * * \mathrm{p}<0,001$

Table 3: Multiple regression results for owner-manager sub-sample: Profitability

Dependent Variable: PROFIT

\begin{tabular}{l|c|c|c|c|c}
\hline Source & DF & Sum of Squares & Mean Square & F Value & Pr>F \\
\hline Model & 5 & 70,124 & 14,025 & 14,33 & 0,0001 \\
\hline Error & 117 & 114,510 & 0,979 & & \\
\hline Corrected Total & 122 & 184,634 & & & \\
\hline
\end{tabular}

$\mathrm{R}^{2}=38,0 \%$

\begin{tabular}{l|c|c|c|c}
\hline Parameter & Estimate & T for H0: Parameter=0 & Pr>[T] & Std Error of Estimate \\
\hline INTERCEPT & 6,037 & 6,38 & 0,0001 & 0,9460 \\
\hline WILLINGNESS & 0,083 & 3,82 & $0,0002^{* * *}$ & 0,0218 \\
\hline FAMILY HARMONY & 0,004 & 0,14 & 0,8911 & 0,0275 \\
\hline INTEREST & 0,147 & 4,19 & $0,0001^{* * *}$ & 0,0352 \\
\hline TRUST & $-0,034$ & $-0,99$ & 0,3259 & 0,0340 \\
\hline RELATION & $-0,008$ & $-0,33$ & 0,7414 & 0,0255 \\
\hline
\end{tabular}

$* \mathrm{p}<0,05$

$* * \mathrm{p}<0,01$

$* * * \mathrm{p}<0,001$

Multiple regression results for the successor subsample: Satisfaction

Table 4 shows that three of the independent variables influence Satisfaction with the succession process. The independent variable Trust in the successor's ability (TRUST) exerts a significant positive influence $(\mathrm{p}<0,001)$ on the dependent variable SATISFIED. This finding implies that the more the owner-manager trusts the successor's abilities and intentions, the more likely they are to be satisfied with the succession process. Family harmony also exerts a significantly $(\mathrm{p}<0,05)$ positive influence on Satisfaction with the succession process. Thus, if family relationships are harmonious during the lead up to succession there is a better chance that successors will be satisfied with the succession process. The positive relationship between Outside interests and the dependent variable shows that the more the owner-manager has interests outside the business, the more satisfied the successor will be with the succession process.

The independent variables in the regression results reported 
in Table 4 explain $19,7 \%$ of the variance in the dependent variable SATISFIED.

Based on the results summarised in Table 4, the null hypothesis $\left(\mathrm{H}^{0 \mathrm{c}}\right)$ of no relationship with the dependent variable Satisfaction with the succession process is thus rejected in respect of Family harmony, Outside interests and Trust in the abilities of the successor.

Multiple regression results for the successor subsample: Future profitability

Table 5 shows that two of the independent variables namely Outside interests (INTEREST) and Willingness to take over the business (WILLING) exert a significant influence on the dependent variable PROFIT. The significance of the relationships are at the $1 \%$ and the $5 \%$ level respectively. In other words, the more the owner-manager has interests outside of the business and the more the successor is willing to take over the business, the more likely the business is of continuing to be profitable.

The independent variables in the regression results reported in Table 5 explain $25,3 \%$ of the variance in the dependent variable Future profitability of the family business.

\section{Table 4: Multiple regression results for successor sub-sample: Satisfaction}

Dependent Variable: SATISFACTION

\begin{tabular}{l|c|c|c|c|c}
\hline Source & DF & Sum of Squares & Mean Square & F Value & Pr>F \\
\hline Model & 5 & 372,462 & 74,492 & 9,95 & 0,0001 \\
\hline Error & 203 & 1519,461 & 7,485 & & \\
\hline Corrected Total & 208 & 1891,923 & & & \\
\hline
\end{tabular}

$\mathrm{R}^{2}=19,7 \%$

\begin{tabular}{|c|c|c|c|c|}
\hline Parameter & Estimate & T for H0: Parameter $=0$ & $\operatorname{Pr}>[T]$ & Std Error of Estimate \\
\hline INTERCEPT & 8,901 & 4,73 & 0,0001 & 1,8710 \\
\hline WILLINGNESS & $-0,0421$ & $-0,89$ & 0,3734 & 0,0472 \\
\hline FAMILY HARMONY & 0,1155 & 2,01 & $0,0453^{*}$ & 0,0573 \\
\hline INTEREST & 0,1978 & 2,58 & $0,0107^{*}$ & 0,0768 \\
\hline TRUST & 0,2418 & 3,62 & $0,0004 * * *$ & 0,0668 \\
\hline RELATION & $-0,0671$ & $-1,12$ & 0,2657 & 0,0601 \\
\hline
\end{tabular}

$* \mathrm{p}<0,05$

$* * \mathrm{p}<0,01$

$* * * \mathrm{p}<0,001$

Table 5: Multiple regression results for successor sub-sample: Profitability

Dependent Variable: PROFITABILITY

\begin{tabular}{l|c|c|c|c|c}
\hline \multicolumn{1}{c|}{ Source } & DF & Sum of Squares & Mean Square & F Value & Pr>F \\
\hline Model & 5 & 161,185 & 32,237 & 13,78 & 0,0001 \\
\hline Error & 203 & 474,795 & 2,339 & & \\
\hline Corrected Total & 208 & 635,981 & & & \\
\hline
\end{tabular}

$\mathrm{R}^{2}=25,3 \%$

\begin{tabular}{l|c|c|c|c}
\hline Parameter & Estimate & T for H0: Parameter $=\mathbf{0}$ & Pr>[T] & Std Error of Estimate \\
\hline INTERCEPT & 4,4422 & 4,23 & 0,0001 & 1,0509 \\
\hline WILLINGNESS & 0,0665 & 2,52 & $0,0125^{*}$ & 0,0264 \\
\hline FAMILY HARMONY & 0,0171 & 0,53 & 0,5942 & 0,0320 \\
\hline INTEREST & 0,1716 & 4,00 & $0,0001^{* * *}$ & 0,0429 \\
\hline TRUST & $-0,0288$ & $-0,77$ & 0,4420 & 0,0373 \\
\hline RELATION & 0,0342 & 1,02 & 0,3107 & 0,0336 \\
\hline
\end{tabular}

$* \mathrm{p}<0,05$

$* * \mathrm{p}<0,01$

$* * * \mathrm{p}<0,001$ 
Based on the results summarised in Table 5, the null hypothesis $\left(\mathrm{H}^{\text {0d }}\right)$ of no relationship with the dependent variable Future profitability is thus rejected in respect of Willingness to take over the business and in respect of Outside interests.

\section{Comparison of results obtained for owner-managers and successors}

While the trust in the successor's abilities and intentions is important to both the owner-manager and successor for their satisfaction with the succession process, the ownermanager's satisfaction is also determined by the willingness of the successor to take over the business. While not so important to the owner-managers, the harmony among family members and the outside interests of the ownermanager are also determinants of the successor's satisfaction with the succession process.

Both owner-managers and successors agree that the willingness of the successor to take over the business and the outside interests of the owner-manager will have a positive influence on the continued profitability of the business.

\section{Management implications}

The empirical results show that the willingness of the successor to take over the business is an important factor that influences both the owner-manager and successor's perception of the continued profitability of the business, as well as the owner-manager's satisfaction with the succession process. Important elements of this factor include whether the successor is looking forward to and has a strong desire to manage the family business, finds it exciting to work in the family business, is committed to continue the family business, and believes that his or her personal development goals could be satisfied in the context of the family business.

The results thus emphasise that successors should join the family business for the right reasons. It is important that parents do not pressurise their offspring to join the business as employees, only providing the option of managerial control if and when their children are interested and possess the necessary qualifications. The owner-manager should thus continuously be on the lookout for opportunities to market the business to other members of the family, providing a realistic, but largely favourable view of each aspect of the family business. Parents who are secretive about their work and always appear overworked and overstressed at home can hardly expect their adult children to be enthusiastic about joining the family business.

In order to make an informed decision about their future, potential successors need to assess their career goals, their family relations and their shareholding in the family business. If they are interested in a future career in the family business, they should openly discuss this possibility with the owner-manager, inter alia establishing what opportunities await within the family business, and also investigate other career possibilities.
Outside work experience may help potential successors to develop an objective view of their talents and abilities and career opportunities, enabling sound decisions on whether to join the family business. It will equip them with more skills and competencies, making them more effective if they do take over the business, especially in the increasingly competitive and fast moving global business environment.

For both the owner-managers and successors, the ownermanager's trust in the successor's abilities and intentions was found to be an important variable for successful succession and influence both groups' satisfaction with the process. The results suggest that if the owner-manager has trust in the integrity and ability of the successor to manage the family business and deliver good business results, and if the successor is allowed to use his own judgment in making business decisions, the better their satisfaction with the succession process will be.

The mechanism that may lead to trust in a successor's abilities in one family business, may not work in another. Sometimes, family perceptions become more positive over time, as they perceive the accomplishments and external recognition of the successor. One owner-manager may view a few years within the business as necessary to develop trust in the successor's abilities, while another may regard tertiary education as a critical ingredient. For some family business owners, the way in which the successor deals with his siblings may be the most important factor in influencing their trust. Therefore, each family business will have to develop its own mechanism to increase the ownermanager's trust in the successor's abilities and intentions.

One way for successors to enhance the predecessor's trust in their abilities is to first prove themselves outside the family business. For the owner-managers within this study the external preparation level of the successor was an important influence on the continued profitability of the business.

The empirical results of this study also revealed that if the owner-manager has interests outside the context of the family business it will have a positive effect on the continued profitability of the business, as well as the successor's satisfaction with the succession process. One can argue that owner-managers who develop strong interests in activities other than the management of the family business generally have an easier time planning their succession. These interests may even mean pursuing new careers outside the business. Rather than seeing leaders off into a carefree retirement, family businesses increasingly find new roles for them, either inside or outside the business.

The empirical results revealed a positive relationship between family harmony and the successor's satisfaction with the succession process. Owner-managers often find it hard to discuss succession issues and a high degree of harmony within the family may make it easier for them to discuss succession issues and set up appropriate systems for preparing the next generation to take over the family business, generally making succession a more tolerable task. A family in conflict may find the succession task very 
difficult.

Succession is a difficult and complicated issue. Therefore, thoughts and feelings about succession need to be discussed through honest and open communication. Family members need to become comfortable spending time together, sharing ideas and different perspectives. Informal family meetings can provide a good forum for the expression of thoughts and feelings about succession. When family members feel included and can voice their complaints, it is often possible to resolve problems collaboratively.

Families that have grown to a multigenerational stage may require a more formal structure, such as a family council. Structures such as family councils provide an ideal setting for educating family members about the rights and responsibilities that come with business ownership and management. They help to clarify the boundaries between the family and the business and provide family members who are not in the business or ownership circles with an opportunity to be heard. These structures can further assist in reducing the likelihood that family concerns will be inappropriately drawn into business decisions. They further provide appropriate settings in which relatives can discuss their concerns so that family events are not dominated by business discussions. A family council can provide the structure to help the family create a shared vision and a 'code of understanding', that is, a family plan. The family council could answer key questions, such as how long it should take for a family member to assume a senior position, what experiences he or she should have before assuming that role, what the compensation should be, and so forth.

Family statements or policy documents describing the relationship between the family and the business are important components of the planning process and may take a variety of forms, some very general and others very specific. A formal family creed could assist in integrating the elements of a succession process. It can help to identify guidelines and rules about entry into the business, career paths, mentoring relationships, training, and executive development. Irrespective of its name, it should lay down the rights and obligations of the family members who are directly involved in the family business. It also serves to record a moral commitment, both towards one another and towards the business. Lastly, it provides a history of events that can help the succession process be successful.

\section{References}

Ackerman, R. 2001. Hearing grasshoppers jump: The story of Raymond Ackerman as told to Denise Prichard. Cape Town: David Philip.

Berenbeim, R.E. 1990. 'How business families manage the transition from owner to professional management', Family Business Review, 3(1):69-110.

Birley, S. 1986. 'Succession in the family firm: The inheritor's view', Journal of Small Business Management, July:37-43.
Bjuggren, P. \& Sund, L. 2001. 'Strategic decision making in intergenerational successions of small- and medium-sized family-owned businesses', Family Business Review, 14(1):11-23.

Brown, R.B. \& Coverley, R. 1999. 'Succession planning in family businesses: A study from East Anglia, U.K.', Journal of Small Business Management, 37(1):93-97.

Ciampa, D. \& Watkins, M. 1999. 'The successor's dilemma', Harvard Business Review, 77(6):161-168.

Chrisman, J.J., Chua, J.H. \& Sharma, P. 'Important attributes of successors in family businesses: An exploratory study', Family Business Review, 12(1):19-34.

Corbetta, G. \& Montemerlo, D. 1998. 'Managing succession in Italian small and medium-size family businesses', The Family Business Network Newsletter, May, 20:8-10.

Correll, R.W. 1989. 'Facing up to moving forward: A third-generation successor's reflections', Family Business Review, 2(1):17-29.

Costa, S.S. 1997. 'Letting go with grace and style'. In Fischetti, M. The family business succession handbook. Philadelphia: Family Business Publishing, pp. 117-121.

Danes, S.M., Rueter, M.A., Kwon, H. \& Doherty, W. 2002. 'Family FIRO model: An application to family business', Family Business Review, 15(1):31-43.

Dickinson, T.M. 2000. 'Critical success factors for succession planning in family businesses'. Unpublished research report in partial fulfilment of the degree of Master in Business Administration, Faculty of Business Administration, University of the Witwatersrand, Johannesburg.

Donckels, R. \& Lambrecht, J. 1999. 'The re-emergence of family-based enterprises in East Central Europe: What can be learned from family business research in the Western World?', Family Business Review, 12(2):171-188.

Donnelley, R.G. 1988. 'The family business', Family Business Review, 1(4):427-445.

Dunn, B. 1999. 'The family factor: The impact of family relationship dynamics on business-owning families during transitions', Family Business Review, 12(1):41-60.

Dyer, W.G. 1994. 'Potential contributions of organizational behavior to the study of family-owned businesses', Family Business Review, 7(2):109-131.

Engine of growth. 1994. Finance Week, 4-10 August:25.

File, K.M. \& Prince, R.A. 1996. 'Attributions for family business failure: The heir's perspective', Family Business Review, 9(2):71-184.

Fleming, P.D. 1997. 'Case study - helping business owners 
prepare for the future', Journal of Accountancy, May: 46-47.

Frane, J., Jennrich, R.I. \& Solomon, P.F. 1990. (as quoted) In Tait, M. 1996. 'Die invloed van geselekteerde bestuursveranderlikes op die diensgehalte by finansiële instellings: 'n Interne bemarkingsperspektief', Unpublished doctoral thesis, University of Port Elizabeth, Port Elizabeth.

Friedman, S.D. 1991. 'Sibling relationships and intergenerational succession in family firms', Family Business Review, 4(1):3-20.

Goldberg, S.D. 1991. 'Factors which impact effective succession in small family-owned businesses: An empirical investigation'. Unpublished doctorial thesis, University of Massachusetts, Massachusetts.

Goldberg, S.D. 1996. 'Research Note: Effective successors in family-owned businesses: significant elements', Family Business Review, 9(2):185-197.

Goldberg, S.D. \& Wooldridge, B. 1993. 'Self-confidence and managerial autonomy: Successor characteristics critical to succession in family firms', Family Business Review, 6(1):55-73.

Hair, J.F., Anderson, R.E., Tatham, R.L. \& Black, W.C. 1995. Multivariate data analysis: With readings. Englewood Cliffs, New Jersey: Prentice Hall.

Hair, J.F., Anderson, RE., Tatham, R.L. \& Black, W.C. 1998. Multivariate data analysis. Fifth edition. Englewood Cliffs, New Jersey: Prentice Hall.

Handler, W.C. 1989. 'Managing the family firm succession process: The next-generation family member's experience'. Unpublished doctoral thesis, Boston University, Boston.

Handler, W.C. 1994. 'Succession in family businesses: A review of the research', Family Business Review, 7(2):133157.

Handler, W.C. \& Kram, K.E. 1988. 'Succession in family firms: The problem of resistance', Family Business Review, 1(4):361-381.

Harveston, P.D., Davis, P.S. \& Lyden, J.A. 1997. 'Succession planning in family business: The impact of owner gender', Family Business Review, 10(4):373-396.

Harvey, M. \& Evans, R.E. 1995. 'Life after succession in the family business: Is it really the end of problems?', Family Business Review, 8(1):3-16.

Hugo, P.F. 1996. 'The alternative business entities available to family businesses with succession as the ultimate goal'. MBA treatise, Graduate School of Business, University of Stellenbosch, Bellville.

Hume, S.A. 1999. 'An assessment of the risk of family business failure'. Unpublished doctoral thesis, Antioch University, New Hampshire.
James, H.S. 1999. 'What can the family contribute to business? Examining contractual relationships', Family Business Review, 12(1):61-71.

Jennrich, R.I. \& Sampson, P.F. 1996. 'Rotation for simple loadings', Psychometrika, 31:313-323.

Lansberg, I.S. 1988. 'The succession conspiracy', Family Business Review, 1(2):119-143.

Lansberg, I. 1999. Succeeding generations: Realising the dreams of families in business. Boston: Harvard Business School Press.

Lansberg, I. \& Astrachan, J.H. 1994. 'Influence of family relationships on succession planning and training: The importance of mediating factors', Family Business Review, 7(1):39-59.

Laubscher, I. 1993. 'An explorative investigation into the nature and scope of the relationship between the founder and successor in a family business with regard to succession'. Unpublished masters research report, Graduate School of Business, University of Stellenbosch, Bellville.

Leach, P. 1994. The Stoy Hayward Guide to the family business. Second edition. London: Kogan Page.

Maas, G. 1999. 'Family businesses in South Africa: A development model'. Paper presented at the Saesba Conference, July 30 - August 1:1-15.

Magretta, J. 1998. 'Governing the family-owned enterprise: An interview with Finland's Krister Ahlstrom', Harvard Business Review, January/February:113-123.

Malone, S.C. 1989. 'Selected correlates of business continuity planning in the family business', Family Business Review, 2(4):341-353.

Matthews, C.H., Moore, T.W. \& Fialko, A.S. 1999. 'Succession in the family firm: A cognitive categorization perspective', Family Business Review, 12(2):159-169.

McConaughy, D.L. \& Phillips, G.M. 1999. 'Founder versus descendants: The profitability, efficiency, growth characteristics and financing in large, public, foundingfamily-controlled firms', Family Business Review, 12(2):123-131.

Meyer, L. 1994. 'The influence of the family-business interaction on strategic management in family business'. A Masters technical report, University of Stellenbosch, Stellenbosch.

Morris, M.H., Williams, K.W., Allen, J.A. \& Avila, R.A. 1997. 'Correlates of success in family business transitions', Journal of Business Venturing, 12:385-401.

Muson, H. 1997. 'Making a career of retirement'. In Fischetti, M. The family business succession handbook. Philadelphia: Family Business Publishing, pp. 121-124. 
Neubauer, F. \& Lank, A.G. 1998. The family business - its governance for sustainability. New York: Routledge.

Okoroafo, S.C. 1999. 'Internationalization of family businesses: Evidence from Northwest Ohio, USA', Family Business Review, 12(2):147-158.

Pierce, J.L. \& Dunham, R.B. 1987. 'Organisational commitment: Pre-employment propensity and initial work experiences', Journal of Management, 13(1):163-178.

Pilversack, J.A \& Scharf, W. 1994. Strategic planning: Keeping it simple. Challenging Assumptions Proceedings of the 1994 Family Firm Institute Conference, Scottsdale, AZ, 5-8 October:127-130.

Ryan, C. 1995. 'Are family businesses better?', Productivity South Africa. March/April:11-13.

Santiago, A.L. 2000. 'Succession experiences in Philippine family businesses', Family Business Review, 13(1):15-40.

Seymour, K.C. 1993. 'Intergenerational relationships in the family firm: The effect on leadership succession', Family Business Review, 6(3):263-281.

Sharma, P. 1997. 'Determinants of the satisfaction of the primary stakeholders with the succession process in family firms'. Unpublished doctoral thesis, University of Calgary, Canada.

Sharma, P., Chua, J.H. \& Chrisman, J.J. 2000. 'Perceptions about the extent of succession planning in Canadian family firms', Canadian Journal of Administrative Sciences, 17(3):233-244.

Shepherd, D.A. \& Zacharakis, A. 2000. 'Structuring family business succession'. Proceedings of the International Council for Small Business, $45^{\text {th }}$ World Conference, Brisbane, Australia, 7-10 June:I-19 (CDRom).

Sorenson, R.L. 1999. 'Conflict management strategies used by successful family businesses', Family Business Review, 12(2):133-145.

Stavrou, E.T. 1999. 'Succession in family businesses: Exploring the effects of demographic factors on offspring intentions to join and take over the business', Journal of Small Business Management, 37(3):43-62.

Stempler, G.L. 1988. 'A study of succession in family owned business's'. Unpublished doctoral thesis, The George Washington University, Washington.

Swogger, G. 1991. 'Assessing the successor generation in family businesses', Family Business Review, 4(4):397-411.

Tharenou, P. 1993. 'A test of reciprocal causality for absenteeism', Journal of Organisational Behavior, 14:269290 .

Venter, E. 2003. 'The succession process in small and medium-sized family businesses in South Africa'.
Unpublished doctoral thesis, The University of Port Elizabeth, Port Elizabeth.

Weinstein, A.G. 1999. 'Family business in the United States - Research and observations'. Forty-fourth World Conference of the International Council for Small Business, Naples, Italy. June:20-23.

Woolard, I. 2002. An overview of poverty and inequality in South Africa. [online] http://www.sarpn.org.za/CountryPoverty Papers/South Africa/july2002/woolard/index. php. 


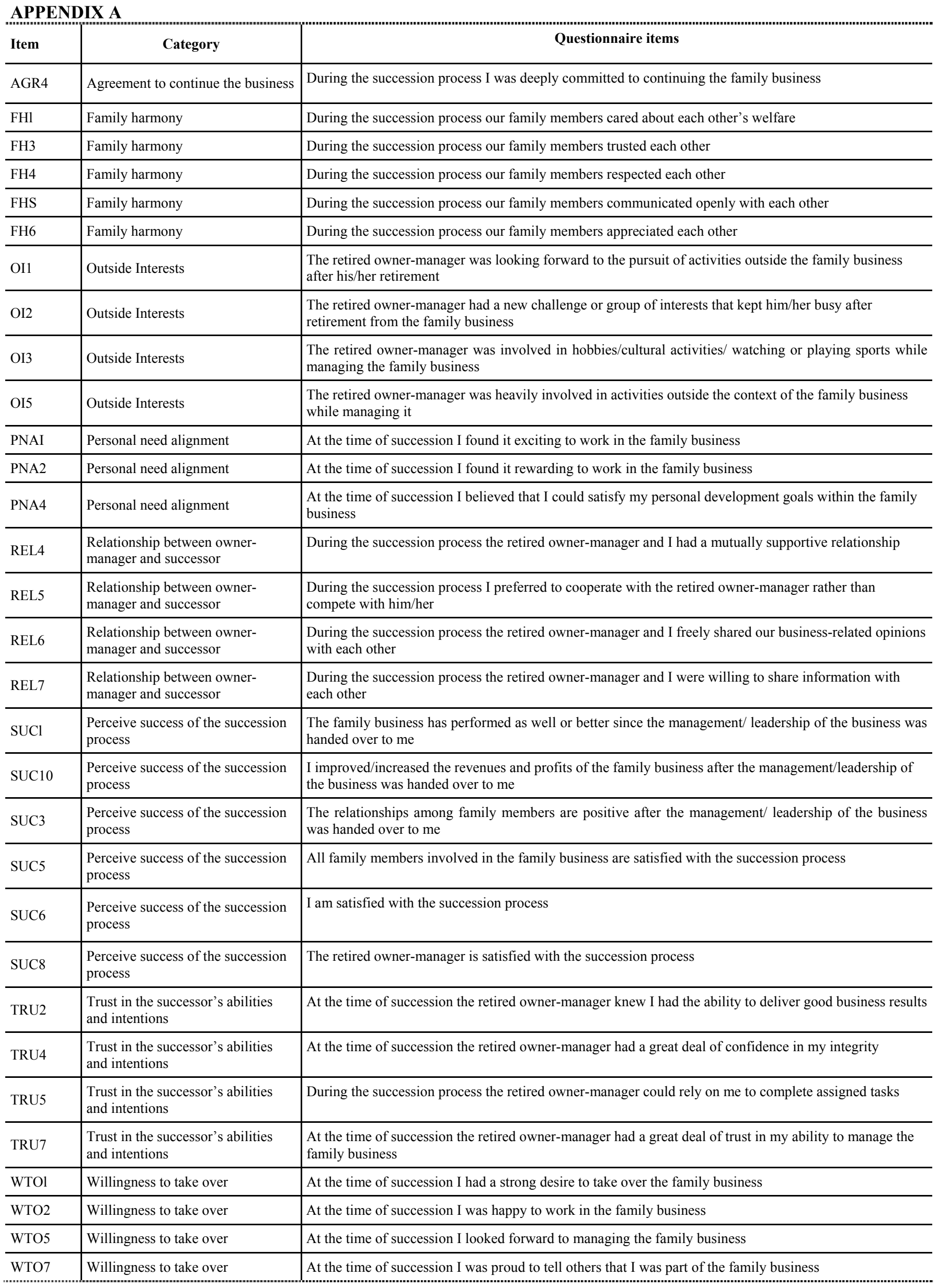


